\title{
Impact of blanching pretreatment on physicochemical properties, and drying characteristics of cabbage (Brassica oleracea)
}

\author{
*Sarkar, A., Rahman, S., Roy, M., Alam, M., Hossain, M.A. and Ahmed, T. \\ Department of Food Engineering and Tea Technology, Shahjalal University of Science and Technology, \\ Sylhet 3114, Bangladesh
}

\begin{abstract}
Article history:
Received: 1 October 2020

Received in revised form: 4

November 2020

Accepted: 1 January 2021

Available Online: 25 April 2021
\end{abstract}

\section{Keywords:}

Blanching pretreatment,

Cabbage,

Color change,

DPPH radical scavenging

activity,

Drying behavior

DOI:

https://doi.org/10.26656/fr.2017.5(2).556

\begin{abstract}
Cabbage (Brassica oleracea) is popular winter vegetables cultivated all over Bangladesh and contains essential nutrients. This study aimed to evaluate the efficacy of pre-blanching on the preservation of cabbage by drying. In this research work, cabbage was blanched at $80^{\circ} \mathrm{C}, 90^{\circ} \mathrm{C}$, and $100^{\circ} \mathrm{C}$ temperature for 12,8 , and $2 \mathrm{mins}$, respectively. Then the samples were dried at $60^{\circ} \mathrm{C}$ maintaining $60 \%$ relative humidity. The moisture and ash content of untreated and treated dried samples was in the range of $16.07 \pm 0.04$ to $10.80 \pm 0.01 \%$ and $5.71 \pm 0.06$ to $3.81 \pm 0.02 \%$, respectively. The total phenolic content in cabbage was $74.47 \pm 0.63 \mathrm{mg} \mathrm{GAE} / 100 \mathrm{~g}$ at $100^{\circ} \mathrm{C}$ blanching temperature for a short time of 2 mins, which was higher compared to $61.91 \pm 0.48 \mathrm{mg}$ GAE $/ 100 \mathrm{~g}$ at $80^{\circ} \mathrm{C}$ for $12 \mathrm{mins}$. It was observed that the antioxidant activity and two water-soluble vitamins-ascorbic acid and beta carotene decreased in pre-blanched dried samples in contrast with fresh ones. Blanching at higher water temperature and a short period was found useful for the retention of total phenolic content and greenness of cabbage. Blanching pre-treatments were also found to have better color retention capacity than untreated dried cabbage. A proper combination of drying time and temperature, along with the incorporation of blanching pretreatment, might be useful to preserve cabbage for a long time.
\end{abstract}

\section{Introduction}

Cabbage is a healthy vegetable consumed throughout the world (Singh et al., 2009). It is typically prepared as a green vegetable, eaten fresh, and often processed as a pickle (Munger, 1988). It is one of the most commonly grown and popular winter crop of Bangladesh and comprises several minerals and vitamins A, B1, B2, C, and dietary fiber (Hossain et al., 2017). The post-harvest losses of vegetables are almost $43 \%$ in Bangladesh (Sharma, 1987). So, a standard post-harvest preservation protocol for most of the vegetables is essential. Drying is considered a well-known strategy utilized to expand the shelf life and ideal quality attributes of a product (Ali et al., 2019). On the contrary, it has a detrimental effect on a dried product's consistency (Alam et al., 2020). During most of the drying processes, color and texture degradation happens. Consequently, it is necessary to develop a drying protocol that reduces the destructive effects of drying on foodstuffs (Chiewchan et al., 2010). Several pretreatment methods can be used following the drying process to keep up or enhance the dried product's quality (Hossain, Mitra, Belal et al., 2020; Sarkar et al., 2020). Blanching is one of the most frequent among them and is normally done before drying, which destroys enzymes responsible for multiple detrimental enzymatic activities. It also tends to retain color and adjust the shape of the substance (Maté et al., 1999; Ahmed et al., 2001).

In addition, before drying, water blanching is a reliable technique that can inhibit enzymatic activity and retain color and nutrients (Xiao et al., 2017). Meanwhile, blanching treatment can alter the food's texture, thereby speeding up the consequent drying process (Castro et al., 2008; Deng et al., 2019). It is also in our interest to incorporate water blanching and drying to conserve cabbages and investigate drying processes and improve consistency. However, it causes undesirable product consistency, e.g., texture loss, soluble nutrients, pigment, and aroma. It may hamper the product's quality by reducing the biochemical compounds in fruits and vegetables through leaching losses. As cabbages are very important sources of the water-soluble vitamin $\mathrm{C}$ and some natural antioxidants (Hossain et al., 2017), hence it is obvious to measure the amount of biochemical components in blanched and dried products and compare them with the fresh produce. Novel blanching techniques 
such as microwave, ohmic heat blanching etc. can reduce nutrient loss and are more efficient. In a previous study, Mo et al. (2006) experimented with the effects of blanching pretreatment on the drying of cabbage enriched with selenium. They found that blanching at $95^{\circ} \mathrm{C}$ for $60 \mathrm{~s}$ retained the vitamin $\mathrm{C}$ and selenium in cabbage. However, very few pieces of literature have been found to use different hot-water blanching temperature and time, and dried cabbage at relatively low temperature to explore suitable blanching and drying condition.

In this context, the primary objective of this research is to implement three different blanching temperature as pretreatment before the drying of cabbage to preserve as many nutrients as possible and to evaluate the impact of blanching on the final product. Three different drying models such as Lewis (Newton), Henderson and Pabis, and Page model were studied to evaluate the drying characteristics of cabbage. Besides, changes in the various quality attributes, including moisture content, antioxidant activity, vitamin $\mathrm{C}$, rehydration capability, and color, were investigated.

\section{Materials and methods}

\subsection{Collection of raw materials}

Fresh and mature cabbages were collected from the Madina market of Sylhet, Bangladesh. The shape and size of each cabbage were carefully selected to avoid large differences. Visual blemishes, diseased, damaged cabbages were discarded.

\subsection{Sample preparation}

Fresh cabbages were cut into $4 \times 1.5 \mathrm{~cm}$ slices using a stainless-steel cutter. The cabbages were then kept inside airtight zip polythene bags before blanching to avoid oxygen.

\subsection{Blanching and drying operation}

The prepared cabbage samples were blanched at $80^{\circ}$ $\mathrm{C}, 90^{\circ} \mathrm{C}$, and $100^{\circ} \mathrm{C}$ temperature with a duration of 12,8 , and 2 mins, respectively, by plunging in a water bath (WB-100D). The blanching pretreatment was done to aid in drying and inactivate the peroxidase enzyme found in cabbage, which may cause alterations of cabbages' quality. The specimens were put in a tray after pretreatment. A constant temperature and humidity chamber (Model: VS-811H-150, Vision Scientific Co. Ltd., South Korea) was used to carry out the drying operation at $60^{\circ} \mathrm{C}$ temperature maintaining $60 \%$ relative humidity (Mo et al., 2006). To calculate the drying characteristics of cabbage, the weight changes were reported at every $1 \mathrm{hr}$ until the difference between two consecutive weights was about $0.01 \mathrm{~g}$. The entire

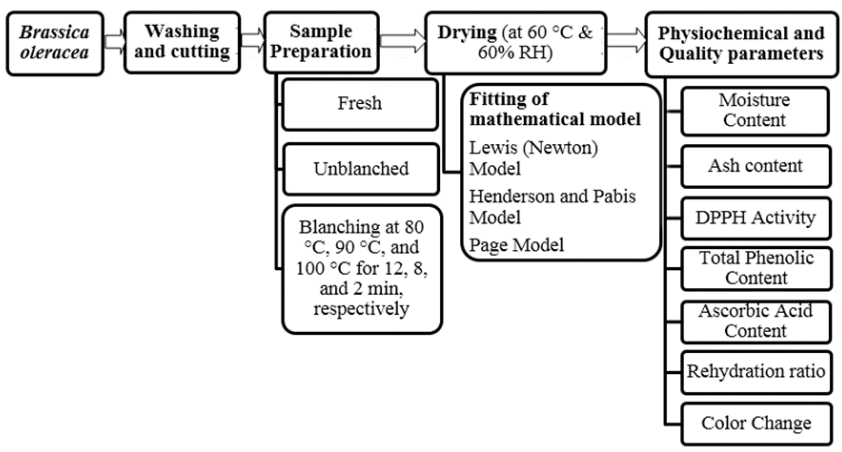

Figure 1. Schematic representation of research design

research design has been illustrated in Figure 1.

\subsection{Determination of moisture content}

By drying a sample at a specific elevated temperature, and disclosing weight loss employing moisture, cabbage's moisture content (dry basis, w/w) was determined by the process of Helvich (1990).

\subsection{Determination of ash content}

The AACC (2000) method was used to estimate the total ash content in cabbage.

\subsection{Determination of DPPH activity}

The modified methods stated by Saikia et al. (2015) and Rahman et al. (2016) were used to determine DPPH activity. About $200 \mu \mathrm{L}$ extracts were added to a $2.8 \mathrm{~mL}$ DPPH solution. Solutions were set in a dark position for half an hour after stirring for $30 \mathrm{~s}$ on the vortex system. The absorbances of the extracts were determined at 517 $\mathrm{nm}$ by using a Spectrophotometer.

DPPH Activity $=\frac{\text { Absorbance of blank }- \text { Absorbance of sample }}{\text { Absorbance of blank }} \times 100 \%$

The

following empirical formula was used to determine the DPPH radical scavenging activity:

\subsection{Estimation of total phenolic content}

The method described by Slinkard and Singleton (1977) was used to estimate the total phenolic content. In short, $20 \mu \mathrm{L}$ of extract were taken into different test tubes. After that, $1.58 \mathrm{~mL}$ of distilled water was added to each of the tubes, accompanied by $100 \mu \mathrm{L}$ of FolinCiocalteu reagent, combined well enough, and finally, $300 \mu \mathrm{L} \mathrm{Na}_{2} \mathrm{CO}_{3}$ was applied within 8 mins. After stirring the samples using a vortex machine, the tubes were kept in the darkness for half an hour at $40^{\circ} \mathrm{C}$. The absorbances of the solutions were then taken at $765 \mathrm{~nm}$ using a T-60 spectrophotometer (PG Instruments Ltd., UK). The 
findings were represented in $\mathrm{mg}$ equivalent gallic acid (GAE)/100 g. There was a selection of standard gallic acid solution taken as blank.

\subsection{Determination of ascorbic acid}

The suggested method of Ranganna (1986) was used to determine the ascorbic acid. 2,6-dichlorophenol indophenols was reduced by ascorbic acid. In this process, the pigment, a blue alkaline solution and red in acid solution, was reduced to a colorless form by ascorbic acid.

\subsection{Determination of $\beta$-Carotene}

The method of Biswas et al. (2011) was used to estimate the Beta Carotene content. An exact $0.025 \mathrm{~g}$ of standard Beta-Carotene was mixed with $5 \mathrm{~mL}$ acetone, and the mixture was kept for 10 mins at a dark place to make the standard solution. Both solutions' absorbance was measured by using a T60-V Spectrophotometer (PG Instruments Ltd., UK) at $450 \mathrm{~nm}$ wavelength.

\subsection{Determination of rehydration ratio}

The dried cabbage samples rehydration ratio (RR) was determined using the method mentioned by Rajkumar et al. (2017). A sample of $2.5 \mathrm{~g}$ was dissolved in boiling water for 10 mins and afterwards moved to a funnel equipped with filter paper Whatman No. 1. With gentle suction, water was withdrawn from the sample until no oozes have been released.

\subsection{Measurement of color change}

The method of Xiao et al. (2012) was used to measure the color change. The color of specimens was measured by utilizing a colorimeter (PCE-CSM 4). L, a, and $b$ values reflect the lightness, redness/greenness, and yellowness/blueness, respectively of the color of

$$
\begin{aligned}
& \mathrm{C}=\sqrt{\left(a^{2}+b^{2}\right)} \\
& \alpha=\tan ^{-1} b / a \\
& \Delta \mathrm{E}=\sqrt{\left(L^{*}-L_{0}\right)^{2}+\left(a^{*}-a_{0}\right)^{2}+\left(b^{*}-b_{0}\right)^{2}}
\end{aligned}
$$

dehydrated samples, whereas $\mathrm{L}_{0} *, \mathrm{a}_{0}{ }^{*}$, and $\mathrm{b}_{0} *$ represent the color of the fresh samples. $\mathrm{C}, \alpha$, and $\Delta \mathrm{E}$ represent the chroma, hue angle, and total color differences, respectively.

\subsection{Mathematical modeling of drying data}

Three different mathematical models viz. Lewis

$$
M R=\frac{M t-M e}{M o-M e}
$$

(Newton): $\mathrm{MR}=\exp (-\mathrm{kt})$, Henderson and Pabis: $\mathrm{MR}=$ aexp(-kt), Page model: $\mathrm{MR}=\left(-\mathrm{kt}^{\mathrm{n}}\right)$ were used to predict the drying behavior. The moisture ratio (MR) of the samples was calculated using the following empirical formula:

$$
\begin{aligned}
& R^{2}=\frac{\sum_{i=1}^{N}(\text { MRexp }, i-M \operatorname{Rexp}, \text { mean }, i)^{2}-(\text { MRpre }, i-M \operatorname{Rexp}, i)^{2}}{\sum_{i=1}^{N}(\text { MRexp }, i-M \operatorname{Rexp}, \text { mean }, j)^{2}} \\
& \text { RMSE }=\sqrt{\frac{\sum_{i=1}^{N}(\text { MRip }-M \operatorname{Mie})^{2}}{N}}
\end{aligned}
$$

Where, Mt, Mo and Me represents the moisture content at a particular time, the primary moisture content and equilibrium moisture content ( $\mathrm{g}$ water/g dry matter), respectively (Izli et al., 2017).

\section{Fitting of mathematical model:}

The correlation coefficient $\left(\mathrm{R}^{2}\right)$ and root mean square of error (RMSE\%) were estimated in conjunction with the process of choosing a mathematical formula that explains the moisture content and time data (Gamli, 2014)

\subsection{Statistical analysis}

All the quantifications were performed in triplicates. The data obtained from the experiments were calculated and analyzed by the SPSS program (Version 20). Data analysis was done by using one-way variance analysis (ANOVA) and Duncan's multiple range test (DMRT) was applied for mean comparison. The data were considered statistically significant among treatments with a $\mathrm{p}$ value $<0.05$. Data has been expressed as mean $\pm \mathrm{SD}$.

\section{Results and discussion}

3.1 Physicochemical properties of fresh and dried cabbage with blanching pretreatment

The moisture and ash content of fresh cabbage was $91.67 \pm 0.02 \%$ and $0.463 \pm 0.06 \%$, respectively. The result represents the loss of moisture content with a higher blanching temperature. This result complies with Taiwo and Adeyemi (2009), which states that the higher the temperature of drying, the greater the moisture loss.

It was found that a rise in blanching temperature caused a decrease in the amount of ash content. The ash content was also reduced in blanched samples in contrast with untreated dried samples. This might be because of the leaching out of minerals from the cabbages during hot water dipping pre-blanching treatments. The result is in line with Makanjuola et al. (2013), who suggest that irrespective of the leafy vegetable under consideration, there was a gradual decrease in ash values during blanching (Table 1). 
Table 1. Physiochemical properties of different cabbage samples

\begin{tabular}{cccccc}
\hline Properties & Fresh & untreated & Blanched $80^{\circ} \mathrm{C}$ & Blanched $90^{\circ} \mathrm{C}$ & Blanched $100^{\circ} \mathrm{C}$ \\
\hline Moisture content (\%) & $91.67 \pm 0.02^{\mathrm{a}}$ & $16.07 \pm 0.04^{\mathrm{b}}$ & $13.92 \pm 0.07^{\mathrm{c}}$ & $11.92 \pm 0.13^{\mathrm{d}}$ & $10.80 \pm 0.01^{\mathrm{e}}$ \\
Ash content (\%) & $0.463 \pm 0.06^{\mathrm{d}}$ & $5.71 \pm 0.06^{\mathrm{a}}$ & $5.77 \pm 0.09^{\mathrm{a}}$ & $4.91 \pm 0.11^{\mathrm{b}}$ & $3.81 \pm 0.02^{\mathrm{c}}$ \\
\hline
\end{tabular}

Values are expressed as mean \pm SD of three independent determinations. Values with the same superscript within the row are not significantly different $(\mathrm{p}<0.05)$.

\subsection{Effect of blanching pretreatment and drying on the bioactive compounds of cabbage}

The results show a significant fall in DPPH radical scavenging activity after drying from the fresh sample $(187.13 \pm 1.07 \%)$. There are little differences in untreated and blanched samples that mean the effect of blanching temperature on the loss of antioxidant activity was the minimum. A similar conclusion was drawn by AbuGhannam and Jaiswal (2015). Most of the antioxidant compounds are heat sensitive. Increased blanching temperature may accelerate the chemical breakdown of bioactive compounds that eventually decrease the production of antioxidants. A similar observation was found by Hossain, Evan, Moazzem et al. (2020), who showed that increasing extraction temperature dramatically reduces the DPPH radical scavenging activity in jackfruit. The general pattern reported is that losses in DPPH activity during the initial blanching process are more noticeable than later, and the factors causing these losses are blanching strategy, variety of cabbage, and blanching time. Though it was reduced slightly, the blanching temperature has a tiny influence, particularly if the applied temperature is within $80-100^{\circ}$ C range (Table 2).

The total phenolic content in untreated dried cabbage $(109.43 \pm 0.51 \mathrm{mg}$ GAE$/ 100 \mathrm{~g})$ was comparatively low than fresh cabbage $(147.36 \pm 0.41 \mathrm{mg} \mathrm{GAE} / 100 \mathrm{~g})$. Furthermore, blanching caused more loss in total phenolic content at $80^{\circ} \mathrm{C}(61.91 \pm 0.48 \mathrm{mg} \mathrm{GAE} / 100 \mathrm{~g})$. Blanching resulted in a significant decrease in the TPC due to thermal deterioration and water leaching (Gonçalves et al., 2010). Joubert (1990) stated that blanching induces the phenolics' solubilization and thus results in a decrease of TPC. Interestingly, the higher blanching temperature indicated a rise in the total phenolic compounds in line with the results of
Yamaguchi et al. (2003), blanching at $95^{\circ} \mathrm{C}$ temperature for 12-14 mins contributed to an enhancement of 5-12\% in the phenolic content. A homogenous trend at $100^{\circ} \mathrm{C}$ was noticed. Blanching can inactivate the polyphenol oxidase enzyme, thus suppressing the oxidation of polyphenols (Table 2).

Vitamin $\mathrm{C}$ removal has been observed during drying. Blanching pretreatment caused a drastic loss of vitamin C. With the rise in blanching temperature, the loss of ascorbic acid was higher than the untreated sample $(34.64 \pm 0.85 \mathrm{mg} / 100 \mathrm{~g})$. Drying at $60^{\circ} \mathrm{C}$ temperature did not cause much destruction of vitamin $\mathrm{C}$ from the fresh sample $(37.23 \pm 0.55 \mathrm{mg} / 100 \mathrm{~g})$ (Table 2). This result reflects the loss of vitamin $\mathrm{C}$ during blanching pretreatment. The water solubility, as well as destructive high temperature, might be responsible for more destruction of vitamin C. A similar result was obtained for pineapple and tomato juice as described by El-Ishaq and Obirinakem (2015).

Dried cabbage samples showed a significant loss in $\beta$ -carotene content. Rather than blanching pretreatment, the drying operation was more responsible for this loss. According to the study of Nascimento et al. (2007), where blanching and drying operation was applied on sweet potato and cassava, blanching did not alter sweet potato's $\beta$-carotene concentration but decreased cassava concentration (16\% loss). Blanching, however, improved $\beta$-carotene stability when dried sweet potato and cassava were stored at room temperature. However, blanching at a higher temperature of $100^{\circ} \mathrm{C}$ for a short duration of 2 mins showed slightly less destruction of $\beta$-carotene $(3.29 \pm 0.15 \mathrm{mg} / 100 \mathrm{~g})$ (Table 2). A similar finding was drawn by Shivhare et al. (2009), where carrot was blanched using $80^{\circ} \mathrm{C}, 85^{\circ} \mathrm{C}, 90^{\circ} \mathrm{C}, 95^{\circ} \mathrm{C}$, and $100^{\circ} \mathrm{C}$ temperatures. Maximum beta carotene was found at $95^{\circ}$ C. This might be because of the inactivation of enzymes

Table 2. Effect of blanching pretreatment and drying on the bioactive compounds of cabbage

\begin{tabular}{ccccc}
\hline Samples & $\begin{array}{c}\text { DPPH scavenging } \\
\text { activity \% }\end{array}$ & $\begin{array}{c}\text { Polyphenol content } \\
(\mathrm{mg} \mathrm{GAE} / 100 \mathrm{~g})\end{array}$ & $\begin{array}{c}\text { Ascorbic acid } \\
(\mathrm{mg} / 100 \mathrm{~g})\end{array}$ & $\begin{array}{c}\beta \text {-Carotene content } \\
(\mathrm{mg} / 100 \mathrm{~g})\end{array}$ \\
\hline Fresh & $187.13 \pm 1.07^{\mathrm{a}}$ & $147.36 \pm 0.41^{\mathrm{a}}$ & $37.23 \pm 0.55^{\mathrm{a}}$ & $38.45 \pm 0.80^{\mathrm{a}}$ \\
Untreated & $86.05 \pm 0.80^{\mathrm{bd}}$ & $109.43 \pm 0.51^{\mathrm{b}}$ & $34.64 \pm 0.85^{\mathrm{b}}$ & $2.22 \pm 0.07^{\mathrm{d}}$ \\
Blanched $\left(80^{\circ} \mathrm{C}\right)$ & $87.34 \pm 1.43^{\mathrm{bc}}$ & $61.91 \pm 0.48^{\mathrm{e}}$ & $8.48 \pm 0.35^{\mathrm{c}}$ & $1.54 \pm 0.13^{\mathrm{e}}$ \\
Blanched $\left(90^{\circ} \mathrm{C}\right)$ & $83.61 \pm 1.27^{\mathrm{cd}}$ & $69.16 \pm 0.73^{\mathrm{d}}$ & $6.23 \pm 0.10^{\mathrm{d}}$ & $2.49 \pm 0.11^{\mathrm{c}}$ \\
Blanched $\left(100^{\circ} \mathrm{C}\right)$ & $82.68 \pm 0.61^{\mathrm{d}}$ & $74.47 \pm 0.63^{\mathrm{c}}$ & $4.14 \pm 0.07^{\mathrm{e}}$ & $3.29 \pm 0.15^{\mathrm{b}}$ \\
\hline
\end{tabular}

Values are expressed as mean $\pm \mathrm{SD}$ of three independent determinations. Values with the same superscript within the row are not significantly different $(\mathrm{p}<0.05)$. 
at $95^{\circ} \mathrm{C}$ blanching temperature for 5 mins. From the results, it can be said $\beta$-carotene is heat-sensitive, but blanching can retain more of it. The reason behind higher $\beta$-carotene retention at higher temperatures conceivably related to the shorter blanching time. Negi and Roy, (2001) stated that blanching before drying improves the preservation of beta-carotene during storage, which might be because of the destruction of the endogenous enzymes.

\subsection{Rehydration ratio of dried cabbage}

Considering that most dehydrated products are rehydrated at their final use (soups, corn flakes, etc.), it is essential to know their compression behavior during rehydration. The rehydration ratio of blanched cabbage at $80^{\circ} \mathrm{C}, 90^{\circ} \mathrm{C}$, and $100^{\circ} \mathrm{C}$ was $8.56 \pm 0.03 \%, 6.67 \pm 0.01 \%$, and $4.18 \pm 0.02 \%$, respectively. With the increase in blanching temperature, there was a decrease in the rehydration ratio. This can be due to the severe structural change in higher blanching temperatures. This complies with the results found by Krokida and Maroulis (2000), who stated that the material's rehydration characteristics are determined by preparation environments, sample constituents, and the nature of the drying-induced chemical and structural alterations.

\subsection{Effect of blanching pretreatment and drying on the color change of cabbage}

The color changes of cabbage subjected to blanching and drying treatment are shown in Table $3 . \mathrm{L}_{0}{ }^{*}, \mathrm{a}_{0}{ }^{*}$, and $\mathrm{b}_{0}{ }^{*}$ values of fresh cabbage were $79.68 \pm 0.03,-7.7 \pm 0.05$, and $23.74 \pm 0.007$, respectively. The reduced $L^{*}$ value in higher temperatures led to dehydrated cabbage becoming a dark color in contrast with a fresh sample. In the meantime, the untreated sample showed a higher value of $\mathrm{L}^{*}$ than the blanched samples. The negative value of $a^{*}$ implies the greenness of the fresh sample. The untreated sample showed higher values of $\mathrm{a}^{*}$ (5.75 \pm 0.02$)$, which indicate red hues. Blanching at $100^{\circ} \mathrm{C}$ showed the lower value of $a^{*}$, which means the cabbages' greenness was retained more in this blanching treatment. The untreated sample showed the least value of $b^{*}(21.11 \pm 0.10)$, which means it was the least yellow. The $\mathrm{C}$ values and $\mathrm{b}^{*}$ values have a good correlation. This indicates the vulnerability of the yellow color in cabbage. Blanching at $100^{\circ} \mathrm{C}$ caused a higher value of $\alpha$, mainly due to the lower value of $\mathrm{a}^{*}$ this indicates retention of green from an orange-red color. Increased blanching temperature showed increased values of $\Delta \mathrm{E}$. The impact of higher temperatures on heat-sensitive products can be attributed to this. The result is in line with Ihl et al. (1998).

\subsection{Validation of empirical models for drying kinetics}

Based on the maximum $\mathrm{R}^{2}$ and minimum RMSE values, the most suitable model(s) designed to predict the drying data were chosen from untreated and pretreated samples. The Page model showed good data fit for all the tested cabbage samples employing $\mathrm{R}^{2}>0.97$ and RMSE $<0.007$. The Lewis model showed the $\mathrm{R}^{2}$ value of $>0.95$ and RMSE $<0.010$. For the Henderson and Pabis model, the value of $\mathrm{R}^{2}$ and RMSE was $>0.94$ and $<0.012$, respectively. The page model is, therefore, suggested as the best model explaining the drying characteristics of untreated and pretreated cabbage samples dehydrated at $60^{\circ} \mathrm{C}$ and $60 \%$ relative humidity (Table 4 ). Similar findings were recorded for red pepper drying (Doymaz and Pala, 2002; Simal et al., 2005; Vega et al., 2007).

Table 3. Effect of blanching pretreatment and drying on color change of cabbage

\begin{tabular}{ccccccc}
\hline \multirow{2}{*}{ Samples } & \multicolumn{5}{c}{ Color Parameter } \\
\cline { 2 - 7 } & $\mathrm{L}^{*}$ & $\mathrm{a}^{*}$ & $\mathrm{~b}^{*}$ & $\mathrm{C}$ & $\alpha$ & $\Delta \mathrm{E}$ \\
\hline Fresh & $79.68 \pm 0.03^{\mathrm{a}}$ & $-7.7 \pm 0.05^{\mathrm{e}}$ & $23.74 \pm 0.007^{\mathrm{b}}$ & $24.94 \pm 0.02^{\mathrm{b}}$ & $72.02 \pm 0.03^{\mathrm{c}}$ & - \\
Untreated & $72.63 \pm 0.03^{\mathrm{b}}$ & $5.75 \pm 0.02^{\mathrm{a}}$ & $21.11 \pm 0.10^{\mathrm{d}}$ & $21.85 \pm 0.02^{\mathrm{c}}$ & $74.76 \pm 0.01^{\mathrm{c}}$ & $15.41 \pm 0.03^{\mathrm{c}}$ \\
Blanched $\left(80^{\circ} \mathrm{C}\right)$ & $67.90 \pm 0.04^{\mathrm{c}}$ & $2.43 \pm 0.02^{\mathrm{c}}$ & $26.76 \pm 0.06^{\mathrm{a}}$ & $26.93 \pm 0.02^{\mathrm{a}}$ & $84.81 \pm 0.04^{\mathrm{ab}}$ & $15.82 \pm 0.10^{\mathrm{c}}$ \\
Blanched $\left(90^{\circ} \mathrm{C}\right)$ & $60.07 \pm 0.03^{\mathrm{d}}$ & $3.63 \pm 0.02^{\mathrm{b}}$ & $24.42 \pm 0.02^{\mathrm{b}}$ & $24.74 \pm 0.03^{\mathrm{b}}$ & $81.54 \pm 0.01^{\mathrm{b}}$ & $22.65 \pm 0.07^{\mathrm{b}}$ \\
Blanched $\left(100^{\circ} \mathrm{C}\right)$ & $56.40 \pm 0.05^{\mathrm{e}}$ & $0.47 \pm 0.07^{\mathrm{d}}$ & $22.29 \pm 0.01^{\mathrm{c}}$ & $22.30 \pm 0.04^{\mathrm{c}}$ & $88.79 \pm 0.04^{\mathrm{a}}$ & $24.71 \pm 0.09^{\mathrm{a}}$ \\
\hline
\end{tabular}

Values are expressed as mean \pm SD of three independent determinations. Values with the same superscript within the row are not significantly different $(\mathrm{p}<0.05)$.

Table 4. $\mathrm{R}^{2}$ and RMSE values of different drying models

\begin{tabular}{ccccccc}
\hline \multirow{2}{*}{$\begin{array}{c}\text { Blanching } \\
\text { Condition }\end{array}$} & \multicolumn{3}{c}{$\mathrm{R}^{2}$} & \multicolumn{3}{c}{ RMSE } \\
\cline { 2 - 7 } & $\begin{array}{c}\text { Lewis (Newtonian) } \\
\text { model }\end{array}$ & $\begin{array}{c}\text { Henderson and } \\
\text { Pabis model }\end{array}$ & Page model & $\begin{array}{c}\text { Lewis (Newtonian) } \\
\text { model }\end{array}$ & $\begin{array}{c}\text { Henderson and } \\
\text { Pabis model }\end{array}$ & $\begin{array}{c}\text { Page model } \\
\text { Untreated }\end{array}$ \\
0.965 & 0.942 & 0.976 & 0.0034 & 0.0014 & 0.0008 \\
Blanched $\left(80^{\circ} \mathrm{C}\right)$ & 0.965 & 0.949 & 0.978 & 0.0049 & 0.0037 & 0.003 \\
Blanched $\left(90^{\circ} \mathrm{C}\right)$ & 0.974 & 0.964 & 0.981 & 0.0083 & 0.0028 & 0.0017 \\
Blanched $\left(100^{\circ} \mathrm{C}\right)$ & 0.981 & 0.973 & 0.992 & 0.0104 & 0.012 & 0.0079 \\
\hline
\end{tabular}




\section{Conclusion}

In this research, an attempt was made to develop an effective preservation technique for fresh cabbages. Drying operation with blanching pretreatment induced the loss of some bioactive compounds of cabbage. Specifically, ascorbic acid and beta carotene content were mostly affected. It was found that higher temperatures and shorter blanching time retained the greenness of cabbage. At $100^{\circ} \mathrm{C}$ blanching temperature, the green color retention was the highest. The Page kinetic model represented the best values. A proper combination of time and temperature, along with the incorporation of modern techniques, might be useful. This information may help to establish an applicable blanching procedure that can be suitable for cabbage and other food products.

\section{Conflict of interest}

The authors declare no conflict of interest.

\section{Acknowledgements}

Authors are thankful to the research centre of Shahjalal University of Science and Technology for their financial support (Project ID:AS/2019/1/28) to conduct the research successfully.

\section{References}

AACC. (2000). Approved methods of the American association of cereal chemists. Methods, 54, 21.

Abu-Ghannam, N. and Jaiswal, A.K. (2015). Blanching as a treatment process: effect on polyphenol and antioxidant capacity of cabbage. In Preddy, V. (Ed.). Processing and impact on active components in food, p. 35-43. London, UK: Elsevier/Academic Press. https://doi.org/10.1016/B978-0-12-404699-3.000056

Ahmed, J., Shivhare, U. and Singh, G. (2001). Drying characteristics and product quality of coriander leaves. Food and Bioproducts Processing, 79(2), 103 -106. https://doi.org/10.1205/096030801750286258

Alam, M., Hossain, M., and Sarkar, A. (2020). Effect of Edible Coating on Functional Properties and Nutritional Compounds Retention of Air Dried Green Banana (Musa sapientum L.). IOSR Journal of Environmental Science, Toxicology and Food Technology (IOSR-JESTFT), 14(2), 51-58.

Ali, L., Shujaat, N., Gilani, S.M., Rehman, H.U., Khan, F., Noor, H., Khan, N.A., Ayaz, U., Ghani, U. and Sadia, H. (2019). Foam Mat Drying of Banana (Musa acuminate) Pulp. Biological Forum - An International Journal, 11(1), 280-283.
Biswas, A., Sahoo, J. and Chatli, M. (2011). A simple UV-Vis spectrophotometric method for determination of $\beta$-carotene content in raw carrot, sweet potato and supplemented chicken meat nuggets. LWT-Food Science and Technology, 44(8), 1809-1813. https://doi.org/10.1016/j.lwt.2011.03.017

Castro, S.M., Saraiva, J.A., Lopes-da-Silva, J.A., Delgadillo, I., Van Loey, A., Smout, C. and Hendrickx, M. (2008). Effect of thermal blanching and of high pressure treatments on sweet green and red bell pepper fruits (Capsicum annuum L.). Food Chemistry, 107(4), 1436-1449. https:// doi.org/10.1016/j.foodchem.2007.09.074

Chiewchan, N., Praphraiphetch, C. and Devahastin, S. (2010). Effect of pretreatment on surface topographical features of vegetables during drying. Journal of Food Engineering, 101(1), 41-48. https:// doi.org/10.1016/j.jfoodeng.2010.06.007

Deng, L.-Z., Pan, Z., Mujumdar, A., Zhao, J.-H., Zheng, Z.-A., Gao, Z.-J. and Xiao, H.-W. (2019). Highhumidity hot air impingement blanching (HHAIB) enhances drying quality of apricots by inactivating the enzymes, reducing drying time and altering cellular structure. Food Control, 96, 104-111. https:// doi.org/10.1016/j.foodcont.2018.09.008

Doymaz, I. and Pala, M. (2002). Hot-air drying characteristics of red pepper. Journal of Food Engineering, 55(4), 331-335. https:// doi.org/10.1016/S0260-8774(02)00110-3

El-Ishaq, A. and Obirinakem, S. (2015). Effect of temperature and storage on vitamin $\mathrm{C}$ content in fruits juice. International Journal of Chemical and Biomolecular Science, 1(2), 17-21.

Gamli, F. (2014). A review based on the relationship among drying, curve fitting and mathematical models in food system. Advance Research in Agriculture and Veterinary Science, 1(2), 47-53.

Gonçalves, E., Pinheiro, J., Abreu, M., Brandão, T.R. and Silva, C.L. (2010). Carrot (Daucus carota L.) peroxidase inactivation, phenolic content and physical changes kinetics due to blanching. Journal of Food Engineering, 97(4), 574-581. https:// doi.org/10.1016/j.jfoodeng.2009.12.005

Helvich, K. (1990). Official methods of analysis: Association of official analytical chemists.

Hossain, M., Evan, M., Moazzem, M., Roy, M. and Zzaman, W. (2020). Response Surface Optimization for Antioxidant Extraction from Jackfruit (Artocarpus heterophyllus Lam.) Seed and Pulp. Journal of Scientific Research, 12(3), 397-409. https://doi.org/10.3329/jsr.v12i3.44459 
Hossain, M., Mitra, S., Belal, M. and Zzaman, W. (2020). Effect of Foaming Agent Concentration and Drying Temperature on Biochemical Properties of Foam Mat Dried Tomato Powder. Food Research, 5 (1), 291-297. https://doi.org/10.26656/fr.2017.5 (1). 372

Hossain, M.J., Khan, G.M., Uddin, M.G., Rahman, M.T. and Hassan, K.M. (2017). Effect of organic fertilizers on major insect infestation in two cabbage cultivars. Journal of Bioscience and Agriculture Research, 14(1), 1183-1189. https:// doi.org/10.18801/jbar.140117.145

Ihl, M., Monsalves, M. and Bifani, V. (1998). Chlorophyllase inactivation as a measure of blanching efficacy and color retention of artichokes (Cynara scolymus L.). LWT-Food Science and Technology, 31(1), 50-56. https://doi.org/10.1006/ fstl.1997.0296

Izli, N., Izli, G. and Taskin, O. (2017). Drying kinetics, color, total phenolic content and antioxidant capacity properties of kiwi dried by different methods. Journal of Food Measurement and Characterization, 11(1), 64-74. https://doi.org/10.1007/s11694-0169372-6

Joubert, E. (1990). Effect of batch extraction conditions on extraction of polyphenols from rooibos tea (Aspalathus linearis). International Journal of Food Science and Technology, 25(3), 339-343. https:// doi.org/10.1111/j.1365-2621.1990.tb01090.x

Krokida, M. and Maroulis, Z. (2000). Quality changes during drying of food materials. Drying Technology in Agriculture and Food Sciences, 4(2), 61-68.

Makanjuola, O.M., Ha, S. and Ajayi, A. (2013). Effects of Blanching and Frozen Storage on the proximate composition of four leafy vegetable widely consumed in Ilaro community, Ogun State, Nigeria. Journal of Global Biosciences ISSN, 2(4), 85-89.

Maté, J., Zwietering, M. and Van't Riet, K. (1999). The effect of blanching on the mechanical and rehydration properties of dried potato slices. European Food Research and Technology, 209(5), 343-347. https://doi.org/10.1007/s002170050506

Mo, H., Zhang, M. and Sun, J. (2006). Effect of drying process parameters on dehydrated cabbage enriched with selenium. Drying Technology, 24(12), 16571663. https://doi.org/10.1080/07373930601031497

Munger, H.M. (1988). Adaptation and breeding of vegetable crops for improved human nutrition, $\mathrm{p}$. 177-184. In Quebedeaux, B. and Bliss, F.A. (Eds.) Horticulture and Human Health. Englewood, New Jersey, USA: Prentice Hall.
Nascimento, P., Fernandes, N., Mauro, M. and Kimura, M. (2007). Beta-carotene stability during drying and storage of cassava and sweet potato. Paper presented at the II International Symposium on Human Health Effects of Fruits and Vegetables - FAVHEALTH 2007. Houston, Texas, USA.

Negi, P.S. and Roy, S.K. (2001). The effect of blanching on quality attributes of dehydrated carrots during long-term storage. European Food Research and Technology, 212(4), 445-448. https:// doi.org/10.1007/s002170000279

Rahman, M., Khan, F., Das, R. and Hossain, M. (2016). Antioxidant activity and total phenolic content of some indigenous fruits of Bangladesh. International Food Research Journal, 23(6), 2399.

Rajkumar, G., Shanmugam, S., de Sousa Galvâo, M., Sandes, R.D.D., Neta, M.T.S.L., Narain, N. and Mujumdar, A.S. (2017). Comparative evaluation of physical properties and volatiles profile of cabbages subjected to hot air and freeze drying. LWT-Food Science and Technology, 80, 501-509. https:// doi.org/10.1016/j.lwt.2017.03.020

Ranganna, S. (1986). Handbook of analysis and quality control for fruit and vegetable products. New Delhi, India: Tata McGraw-Hill Education.

Saikia, S., Mahnot, N.K. and Mahanta, C.L. (2015). Effect of spray drying of four fruit juices on physicochemical, phytochemical and antioxidant properties. Journal of Food Processing and Preservation, 39(6), 1656-1664. https:// doi.org/10.1111/jfpp.12395

Sarkar, A., Ahmed, T., Alam, M., Rahman, S. and Pramanik, S.K. (2020). Influences of Osmotic Dehydration on Drying Behavior and Product Quality of Coconut (Cocos nucifera). Asian Food Science Journal, 15(3), 21-30. https:// doi.org/10.9734/afsj/2020/v15i330153

Sharma, S. (1987). Training Manual of Vegetables and Social Forestry. MOA/FAO/UNDP (Project BGD/79/034). Dhaka, Bangladesh: Department of Agricultural.

Shivhare, U., Gupta, M., Basu, S. and Raghavan, G. (2009). Optimization of blanching process for carrots. Journal of Food Process Engineering, 32(4), 587-605. https://doi.org/10.1111/j.17454530.2007.00234.x

Simal, S., Garau, C., Femenia, A. and Rosselló, C. (2005). Drying of red pepper (Capsicum annuиm): water desorption and quality. International Journal of Food Engineering, 1(4), 1. https:// doi.org/10.2202/1556-3758.1022 
Singh, B., Sharma, S. and Singh, B. (2009). Heterosis for mineral elements in single cross-hybrids of cabbage (Brassica oleracea var. capitata L.). Scientia Horticulturae, 122(1), 32-36. https:// doi.org/10.1016/j.scienta.2009.04.007

Slinkard, K. and Singleton, V.L. (1977). Total phenol analysis: automation and comparison with manual methods. American Journal of Enology and Viticulture, 28(1), 49-55.

Taiwo, K. and Adeyemi, O. (2009). Influence of blanching on the drying and rehydration of banana slices. African Journal of Food Science, 3(10), 307315.

Vega, A., Fito, P., Andrés, A. and Lemus, R. (2007). Mathematical modeling of hot-air drying kinetics of red bell pepper (var. Lamuyo). Journal of Food Engineering, 79(4), 1460-1466. https:// doi.org/10.1016/j.jfoodeng.2006.04.028

Xiao, H.-W., Pan, Z., Deng, L.-Z., El-Mashad, H. M., Yang, X.-H., Mujumdar, A. S., Gao, Z.-J. and Zhang, Q. (2017). Recent developments and trends in thermal blanching-A comprehensive review. Information Processing in Agriculture, 4(2), 101127. https://doi.org/10.1016/j.inpa.2017.02.001

Xiao, H.W., Yao, X.D., Lin, H., Yang, W.X., Meng, J.S. and Gao, Z.J. (2012). Effect of SSB (superheated steam blanching) time and drying temperature on hot air impingement drying kinetics and quality attributes of yam slices. Journal of Food Process Engineering, 35(3), 370-390. https:// doi.org/10.1111/j.1745-4530.2010.00594.x

Yamaguchi, T., Katsuda, M., Oda, Y., Terao, J., Kanazawa, K., Oshima, S., Inakuma, T., Ishiguro, Y., Takamura, H. and Matoba, T. (2003). Influence of polyphenol and ascorbate oxidases during cooking process on the radical-scavenging activity of vegetables. Food Science and Technology Research, 9(1), 79-83. https://doi.org/10.3136/fstr.9.79 